\title{
Analysis of the Working Position of Sandal Operator Using RULA and REBA Approach
}

\author{
at Sisman Corporation (SISCO)
}

\author{
Rullie Annisa \\ Department of Industrial Engineering \\ University of Trunojoyo Madura \\ Bangkalan, Indonesia \\ rullie.annisa@trunojoyo.ac.id
}

\begin{abstract}
One of the determinant factors in work productivity is an employee. An employee who feels comfortable with his work activities can increase productivity. In implementing the comfort for the employees, it is necessary to pay attention to the work position or posture which is ergonomic. this is because an ergonomic working environment could minimize injury or work accidents occuring. Ergonomics is the study of the interaction between humans and other elements in a system. Ergonomics approach in analyzing work position uses the REBA (Rapid Entire Body Assessment) and RULA (Rapid Upper Limb Assessment) method. The objective of this research is to analyse of operators' working position when producing sandals using the RULA and REBA method at SISCO. Based on the results and analysis of the work position or posture of SISCO operators when carrying out production activities using REBA or RULA method approach, results indicated that either in the work position/posture A or standing, it has a high risk level with a score of 9 on REBA and 8 on RULA. It means that the work position is not recommended because of the high risk of injury, thus it needs an improvement from the operator's position or the workplace. In position B (squat) and C (sit) have a score of 5 on RULA and REBA which have a medium level. It means that it needs an improvement.
\end{abstract}

Keywords-Ergonomics; RULA; REBA; Work Position

\section{INTRODUCTION}

SISMAN CORPORATION (SISCO) is a company focusing on sandals production. The sandals produced by SISCO can be regarded as the unique one, because the customers can order sandals based on their preferences, including color, name and design. The production process that took place still uses a man-machine system, so that the operator has full control in carrying out its activities. In practice, the production activities carried out manually are still based on personal comfort without considering ergonomic aspects, because of the absence of standard work instructions for each work activity. Thus, the activities and work positions performed by employees or operators often result in complaints of waist pain and neck by employees or operators. It highly influence affects the operators' work productivity. The productivity is determined by several factors, including human resources, namely employees. Every employee is required to do the right things and work the things right, no matter where they are placed [10]. One of the ways that can be conducted to increase productivity is through paying attention to the position or comfortable and ergonomic working posture for workers [3]. Measuring the operators' position is very important because the position at work greatly affects production activities. Ergonomic work position makes the operators focus more on their work and minimizes injury or work accidents [11]

Ergonomics is the study of the interaction between humans and other elements in a system [4]. Ergonomics approach in analyzing work positions, uses the RULA and REBA method. REBA (Rapid Entire Body Assessment) is a method developed in the field of ergonomics and can be used quickly to assess the work position or posture of the neck, back, arm and leg of operators [7]. The RULA (Rapid Upper Limb Assessment) method is a method a survey developed for ergonomic investigations about the workplace which is related to upper limb disorders [1][5]. Based on the background above, the focus of the observation in this study is to analyse of operators working position when producing sandals using the RULA and REBA method at SISCO.

\section{LITERATURE REVIEW}

The utilization of human power in industry in Indonesia is still very dominant. One of them is the production activity with man machine system. This is because the operator has full control in carrying out its activities. In practice, the production activities carried out by employees are still based on personal comfort without considering the ergonomic aspects especially the operators' work posture itself, so that the work posture becomes an interesting matter to be studied further. One of working posture analysis methods is RULA and REBA

\section{A. Rapid Upper Limb Assessment (RULA)}

This RULA method designed by [5] used to analyze body posture to investigate disorders of the upper limbs, by providing a calculation of the level of musculoskeletal load in a work that has a risk to the body part from the stomach to the neck or upper limbs. The input in this method is in the form of posture (palms, upper arms, forearms, back and neck), the load lifted, the energy used (static / dynamic), and the amount of work. Each movement activity is given a score that has been set on The RULA Scoring Sheet. RULA is developed as a 
method to detect work posture as a cause of risk factors and is designed to assess employees and find out musculoskletal loads that may cause disorders on the upper limbs.

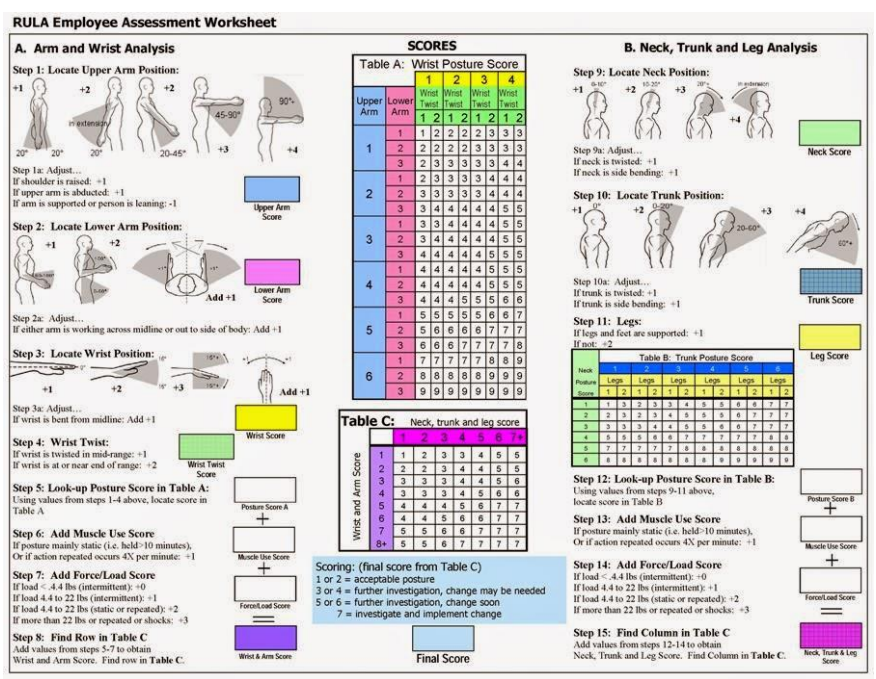

Fig. 1. The RULA Scoring Sheet

The RULA method uses a diagram of body posture and three score tables in determining the evaluation of risk factors. The risk factors which have been investigated as external load factors consist of : Number of movements, static muscle work, power/strength, determination of work posture by equipment, working time without rest[5][1]. the RULA methods is a tool requires no special equipment in providing a quick assessment of the postures of the neck, trunk and upper limbs along with muscle function and the external loads experienced by the body A coding system is used to generate an action list which indicates the level of intervention required to reduce the risks of injury due to physical loading on the operator[5].

\section{B. Rapid Entire Body Assessment (REBA)}

REBA is a method used to analyze a work based on body position. This method is designed by [6] to evaluate work or activity, where it has a tendency to cause discomfort such as fatigue in the spine, arms, neck and so on. The REBA method evaluates work by giving a score based on 5 different level activities. The result indicates the level of risk faced by employees or operators in carrying out their work activities and the workload they bear. The risk of the work is related to muscle and posture disease.

In REBA analysis, there are two categories of body posture, namely category A and B. Category A consists of body, neck and legs, while category B consists of upper and lower arms and wrists for left and right movements. Each category has a complete body posture rating scale with additional notes that can be used as consideration for repair design. After assessing body posture, it scores the load or energy used and the factors associated with the coupling [6][7]. The score for each body posture is obtained from the REBA assessment table. The total score in category $\mathrm{A}$ is the score obtained from the total score of body posture contained in table A with the score of the load or power. The total score in category B is the score obtained from the sum of the body posture scores found in table B with the coupling score for both hand. REBA score is obtained by looking at the score of category $\mathrm{A}$ and $\mathrm{B}$ in table $\mathrm{C}$ in order to obtain the score of $\mathrm{C}$. Then it is added to the score of the activity. While the level of working risk is obtained from the REBA decision table[2][6][7]. REBA has been developed to "ll a perceived need for a practitioner's "eld tool,specically designed to be sensitive to the type of unpredictable working postures found in health care and other service industries [7]

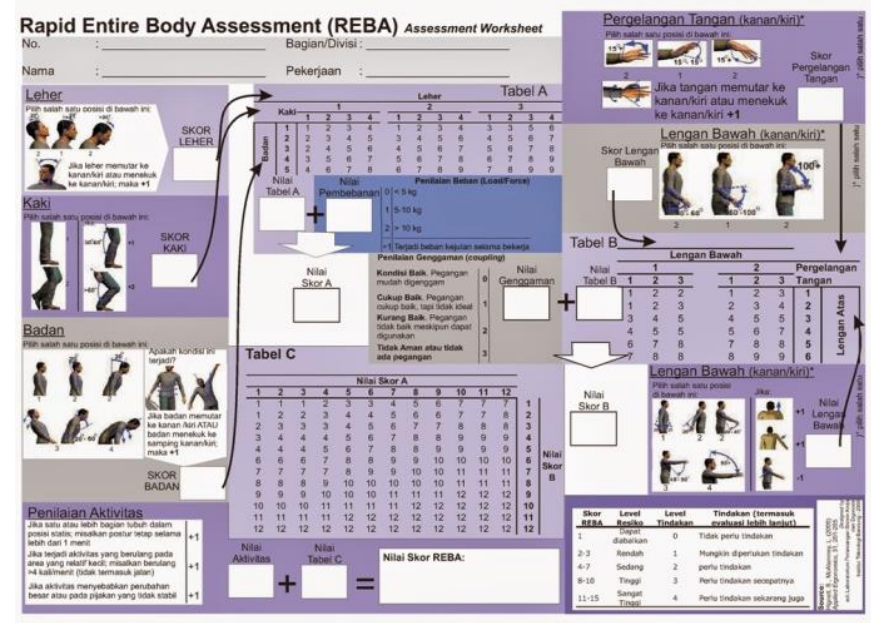

Fig. 2. The REBA Scoring Sheet

\section{RESEARCH APPROACH}

The method used in solving the problem of SISCO operators' work position or posture which has risk of injury is by modeling the problem using position or posture analysis with RULA and REBA analysis approach and visio software. The position / work posture using the REBA method approach is divided into three work positions namely work position A, work position $\mathrm{B}$ and work position $\mathrm{C}$, while in the RULA method approach is divided into three work positions including standing work position, squat work position and sitting work position.

\section{RESULT AND ANALYSIS}

\section{A. Method of Work Position A}

The work position A consists of three parts of the work position, namely the sponging work position, the name of the sponge and the plucking of the rest of sandals, because all of them are the same. Thus, it is enough to take REBA measurements in one of the work positions. 
TABLE I. REBA METHOD OF WORK POSITION A

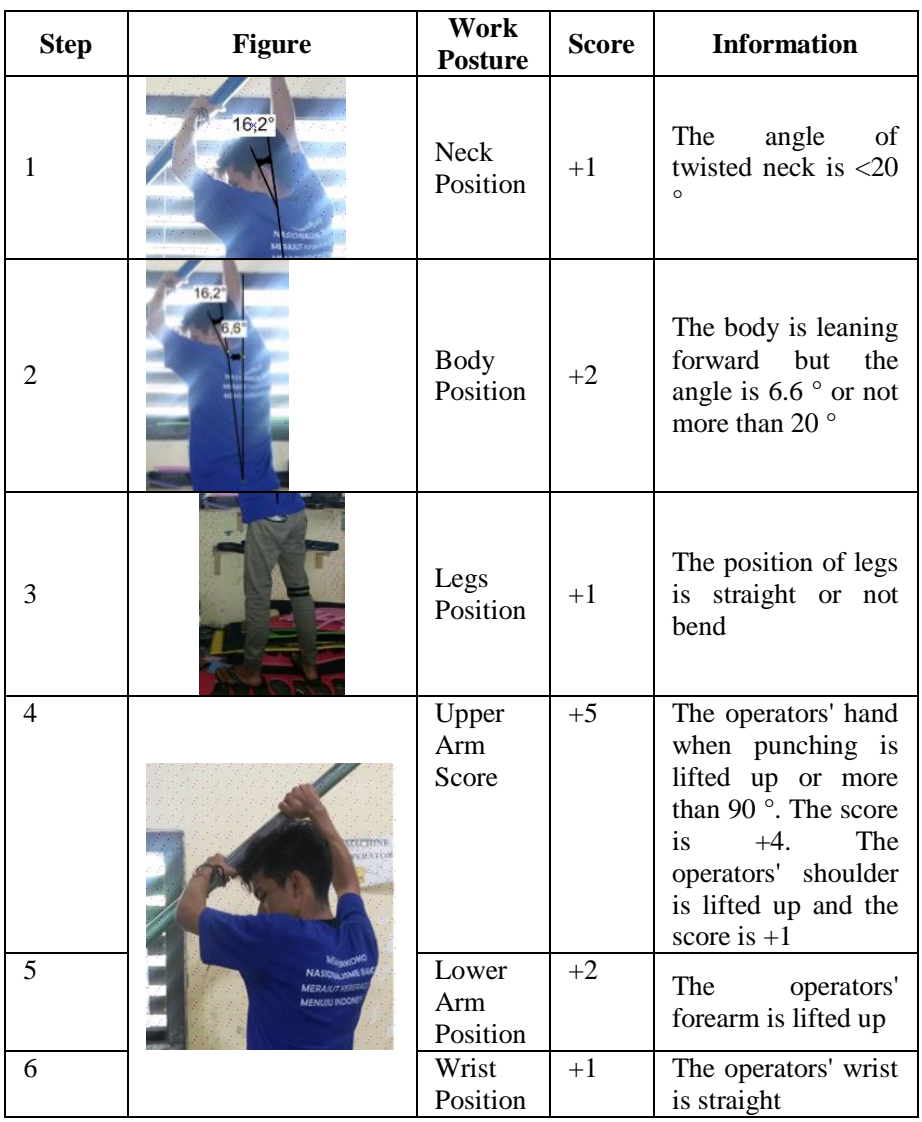

Based on the score in step 1-3, the score on the table A score is 2 is, while the score for the load is +2 that the load when carrying out the slurry of about $8 \mathrm{~kg}$ (17.673 pounds). With that condition, there is a shock during the sweep process, so total score A is 4. Likewise the score in steps 4-6, the score obtained in table B is +7 , while the score for the handle or coupling is +0 because the handle of the operator is good, so the total score B is 7. The operators' activity is repeating and the activity causes a large or unstable change, so the additional activity score is +2 , so the REBA final score uses Table $\mathrm{C}$ which is added with an additional score for the activity, where the previous step score A is 4, score B is 7 and score an additional 2. It is 9 and is the REBA score on posture / work position A.

\section{B. REBA Method of Work Position B}

The work position $B$ consists of three parts, namely the working position of giving glue to the bottom of the sandal and gluing the base of the sandal with a sponge. Because all of them are the same, so it just take REBA measurements in one of the work positions.
TABLE II. REBA METHOD OF WORK POSITION B

\begin{tabular}{|c|c|c|c|c|}
\hline Step & Figure & $\begin{array}{c}\text { Work } \\
\text { Posture }\end{array}$ & Score & Information \\
\hline 1 & & $\begin{array}{l}\text { Neck } \\
\text { Position }\end{array}$ & +2 & $\begin{array}{l}\text { The angle of } \\
\text { twisted neck is > } \\
20^{\circ}\end{array}$ \\
\hline 2 & & $\begin{array}{l}\text { Body } \\
\text { Position }\end{array}$ & +3 & $\begin{array}{l}\text { The body is } \\
\text { leaning forward at } \\
\text { an angle of } 29.7^{\circ} \\
\text { or more than } 20^{\circ}\end{array}$ \\
\hline 3 & & $\begin{array}{l}\text { Legs } \\
\text { Position }\end{array}$ & +2 & $\begin{array}{l}\text { The legs position } \\
\text { bend }\end{array}$ \\
\hline 4 & & $\begin{array}{l}\text { Upper } \\
\text { Arm } \\
\text { Score }\end{array}$ & +2 & $\begin{array}{l}\text { The operators' } \\
\text { hand when gluing } \\
\text { is at an angle of } \\
42.3 \circ \text { measured } \\
\text { from the operators' } \\
\text { body and shoulders } \\
\text { are stable or not } \\
\text { lifted }\end{array}$ \\
\hline 5 & & $\begin{array}{l}\text { Lower } \\
\text { Arm } \\
\text { Position }\end{array}$ & +1 & $\begin{array}{l}\text { The operators' } \\
\text { forearm which is at } \\
\text { an angle of } 80^{\circ} \text { - } \\
100^{\circ} \text { is } 93.2^{\circ}\end{array}$ \\
\hline 6 & & $\begin{array}{l}\text { Wrist } \\
\text { Position }\end{array}$ & +2 & $\begin{array}{l}\text { The operators' } \\
\text { wrist tends to bend }\end{array}$ \\
\hline
\end{tabular}

Based on the score in steps 1-3, the score obtained in the table A score is +5 while the score for the load is +0 that when carrying out the gluing of $<1 \mathrm{~kg}(<2.20462$ pounds) with the condition of shaking during the puncing process occurs, the total score A is 5. Likewise the score in steps 4-6, the score obtained in table $\mathrm{B}$ is +2 , while the score for the handle or coupling is +0 because the handle of the operator is good, so the total score $\mathrm{B}$ is +2 . Due to the existence of repeating operators' activity, the additional activity score is +1 , so that the final REBA score uses Table $\mathrm{C}$ which is added with an additional score for the activity, where the previous score $\mathrm{A}$ is 5 , the score B is 2 and the additional score is 1 . It is 5 and is a REBA score on workposture or position B.

\section{REBA Method of Work Position C}

The work position $\mathrm{C}$ consists of two work positions, namely the working position of the sanding and the installation of sandals telli. Because both are the same, it just take REBA measurements in one of the work positions.

TABLE III. REBA METHOD OF WORK POSITION C

\begin{tabular}{|l|c|l|l|l|}
\hline Step & Figure & $\begin{array}{l}\text { Work } \\
\text { Posture }\end{array}$ & Score & Information \\
\hline 1 & $17,4^{\circ}$ & & & \\
& & $\begin{array}{l}\text { Neck } \\
\text { Position }\end{array}$ & +1 & $\begin{array}{l}\text { The angle of } \\
\text { twisted neck } \\
\text { is }<20^{\circ}\end{array}$ \\
\hline
\end{tabular}




\begin{tabular}{|c|c|c|c|c|}
\hline Step & Figure & $\begin{array}{l}\text { Work } \\
\text { Posture }\end{array}$ & Score & Information \\
\hline 2 & & $\begin{array}{l}\text { Body } \\
\text { Position }\end{array}$ & +2 & $\begin{array}{l}\text { The body is } \\
\text { leaning } \\
\text { forward at an } \\
\text { angle of } 12.5 \\
{ }^{\circ} \text { or less than } \\
20\end{array}$ \\
\hline 3 & & $\begin{array}{l}\text { Legs } \\
\text { Position }\end{array}$ & +2 & $\begin{array}{l}\text { The legs } \\
\text { position bend }\end{array}$ \\
\hline 4 & & $\begin{array}{l}\text { Upper } \\
\text { Arm } \\
\text { Score }\end{array}$ & +2 & $\begin{array}{l}\text { The } \\
\text { operators' } \\
\text { hand when } \\
\text { punching and } \\
\text { being lifted at } \\
\text { an angle of } \\
52.3 \\
\text { measured } \\
\text { from the } \\
\text { operators' } \\
\text { body and } \\
\text { shoulders are } \\
\text { stable or not } \\
\text { lifted }\end{array}$ \\
\hline 5 & & $\begin{array}{l}\text { Lower } \\
\text { Arm } \\
\text { Position }\end{array}$ & +2 & $\begin{array}{l}\text { The } \\
\text { operators' } \\
\text { forearm at an } \\
\text { angle of > } \\
100 \text { ० is } \\
106.4^{\circ}\end{array}$ \\
\hline 6 & & $\begin{array}{l}\text { Wrist } \\
\text { Position }\end{array}$ & +2 & $\begin{array}{l}\text { The } \\
\text { operators' } \\
\text { wrist tends to } \\
\text { bend }\end{array}$ \\
\hline
\end{tabular}

Based on the scores in steps 1-3, the score obtained in the table of score $\mathrm{A}$ isa +2 , while the score for the load obtained is +0 that when sanding about $<5 \mathrm{~kg}$ or $<11$ pounds, the total score A is 2. Likewise the score in steps $4-6$, the score in table $\mathrm{B}$ is +5 , while the score for the handle or coupling is +0 because the handle of the operator is good, so the total score of $\mathrm{B}$ is +5 . Due to the existence of repeating operators' activity, the additional score of the activity is +1 , so the REBA final score uses Table $\mathrm{C}$ which is added with an additional score for the activity, where the previous score A is 2, the score B is 5 and the additional score is 1 . It is 5 is and is a REBA score on the work posture/position $\mathrm{C}$.

Analysis of REBA score aims to determine the level of injury risk for the operator and to determine whether the corrective action is needed from the operators' position or workplace in accordance with the score produced. Based on the data above categorized in the REBA level action, the work position $A$ is the highest category among the others. It is 9 , so that for corrective action it needs to be conducted immediately, otherwise the operator will experience fatigue faster and also the operator has a greater chance of experiencing injury risk.

\section{RULA Method of Standing Work Position}

TABLE IV. RULA METHOD OF STANDING WORK POSITION

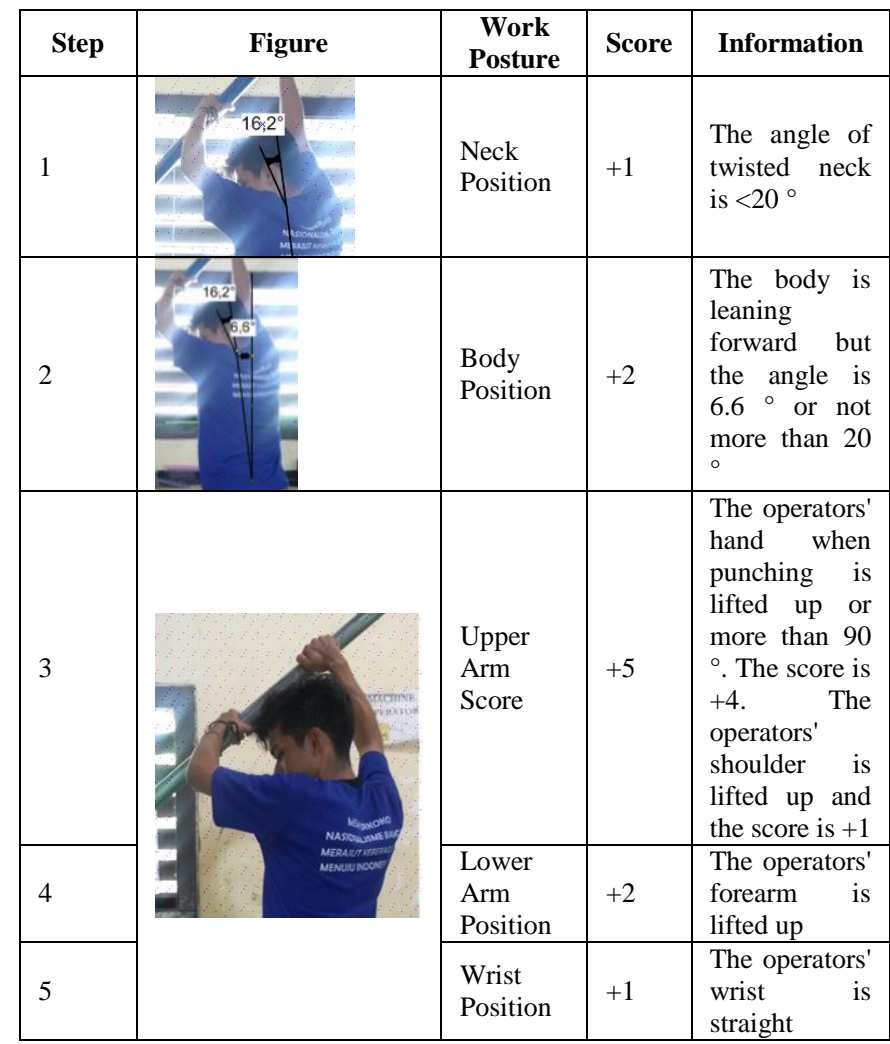

Based on the score in step 1-2, the score obtained in the table of score $\mathrm{A}$ is +2 , while the score for the load gained is +2 . The description of the load is when carrying out the slurry of about $8 \mathrm{~kg}$ (17.673 pounds), there is a shock in punching process, so the total score A is 4 . As well as the score in step 35 , the score in table B is +7 . While the score for the handle or coupling is +0 because the handle is good, so the total score of $\mathrm{B}$ is +7 . Through repeating operator activities, these activities cause large or unstable changes, so the additional activity score is +2 . The final RULA score uses Table $C$ which is added with additional scores for activities, where the previous step A score is +4 , score $B$ is +7 and additional score is +2 . It is exactly 8 and is the RULA score on the standing work posture / position.

\section{E. RULA Method of Squat Position}

TABLE V. RULA Method of SQUAT Position

\begin{tabular}{|l|l|l|l|l|}
\hline Step & Figure & $\begin{array}{l}\text { Work } \\
\text { Posture }\end{array}$ & Score & Information \\
\hline 1 & $\begin{array}{l}\text { Neck } \\
\text { Position }\end{array}$ & +2 & $\begin{array}{l}\text { The angle of } \\
\text { twisted neck } \\
\text { is }>20^{\circ}\end{array}$ \\
\cline { 2 - 4 } 2 & $\begin{array}{l}\text { The body is } \\
\text { leaning } \\
\text { forward at an } \\
\text { angle of 29.7 } \\
\text { or more than } \\
20^{\circ}\end{array}$ \\
\hline
\end{tabular}




\begin{tabular}{|c|c|c|c|c|}
\hline Step & Figure & $\begin{array}{l}\text { Work } \\
\text { Posture }\end{array}$ & Score & Information \\
\hline 3 & & $\begin{array}{l}\text { Upper } \\
\text { Arm } \\
\text { Score }\end{array}$ & +2 & $\begin{array}{l}\text { The operators' } \\
\text { hand when } \\
\text { gluing is at an } \\
\text { angle of } 42.3 \\
\text { o measured } \\
\text { from the } \\
\text { operators' } \\
\text { body and } \\
\text { shoulders are } \\
\text { stable or not } \\
\text { lifted }\end{array}$ \\
\hline 4 & & $\begin{array}{l}\text { Lower } \\
\text { Arm } \\
\text { Position }\end{array}$ & +1 & $\begin{array}{l}\text { The operators' } \\
\text { forearm } \\
\text { which is at an } \\
\text { angle of } 80^{\circ}- \\
100^{\circ} \text { is } 93.2\end{array}$ \\
\hline 5 & & $\begin{array}{l}\text { Wrist } \\
\text { Position }\end{array}$ & +2 & $\begin{array}{l}\text { The operators' } \\
\text { wrist tends to } \\
\text { bend }\end{array}$ \\
\hline
\end{tabular}

Based on the score in step 1-2, the score obtained in table A score is +5 , while the score for the load is +0 that when carrying out the gluing around $<1 \mathrm{~kg}(<2.20462$ pounds) with the condition of shaking during the punching process occurs, the total score A is 5. Likewise the score in step 3-5, the score obtained in table $\mathrm{B}$ is equal to +3 , while the score for the handle or coupling is +0 because the handle of the operator is good, so the total score of $\mathrm{B}$ is +3 . There is repeating operator activity, so that the additional activity score is +1 and the final score of RULA uses Table $\mathrm{C}$ which is added with an additional score for the activity, where the previous step A score is 5, score $\mathrm{B}$ is +3 and additional score is 1 . It is 5 and is the RULA score on the squat posture / work position.

\section{F. RULA Method of Sitting Position}

TABLE VI. RULA METHOD OF SITTING POSITION

\begin{tabular}{|c|c|c|c|c|}
\hline Step & Figure & $\begin{array}{c}\text { Work } \\
\text { Posture }\end{array}$ & Score & Information \\
\hline 1 & & $\begin{array}{l}\text { Neck } \\
\text { Position }\end{array}$ & +1 & $\begin{array}{l}\text { The angle of } \\
\text { twisted neck is } \\
<20^{\circ}\end{array}$ \\
\hline 2 & & $\begin{array}{l}\text { Body } \\
\text { Position }\end{array}$ & +2 & $\begin{array}{l}\text { The body is } \\
\text { leaning } \\
\text { forward at an } \\
\text { angle of } 12.5^{\circ} \\
\text { or less than } 20\end{array}$ \\
\hline 3 & & $\begin{array}{l}\text { Upper } \\
\text { Arm } \\
\text { Score }\end{array}$ & +3 & $\begin{array}{l}\text { The operators' } \\
\text { hand when } \\
\text { punching and } \\
\text { being lifted at } \\
\text { an angle of } \\
52.3 \\
\text { measured from } \\
\text { the operators' } \\
\text { body and } \\
\text { shoulders are } \\
\text { stable or not } \\
\text { lifted }\end{array}$ \\
\hline
\end{tabular}

\begin{tabular}{|c|c|c|c|c|}
\hline Step & Figure & $\begin{array}{c}\text { Work } \\
\text { Posture }\end{array}$ & Score & Information \\
\hline 4 & & $\begin{array}{l}\text { Lower } \\
\text { Arm } \\
\text { Position }\end{array}$ & +2 & $\begin{array}{l}\text { The operators' } \\
\text { forearm at an } \\
\text { angle of }>100 \\
{ }^{\circ} \text { is } 106.4^{\circ}\end{array}$ \\
\hline 5 & & $\begin{array}{l}\text { Wrist } \\
\text { Position }\end{array}$ & +2 & $\begin{array}{l}\text { The operators' } \\
\text { wrist tends to } \\
\text { bend }\end{array}$ \\
\hline
\end{tabular}

Based on the score in step 1-2, the score obtained in the table of score $\mathrm{A}$ is +2 , while the score for the load is +0 that when sanding about $<5 \mathrm{~kg}$ or $<11$ pounds, the total score $\mathrm{A}$ is 2 . Likewise the score in step $3-5$, the score in table $\mathrm{B}$ is +5 , while the score for the handle or clutch is +0 because the handle of the operator is good, so the total score B is +5 . There is repeating operator activity, so that the additional activity score is +1 and the final score of RULA uses Table $\mathrm{C}$ which is added with an additional score for the activity, where the previous step A score is 2, the B score is 5 and the additional score is 1 . It is 5 and is the RULA score on the sitting work posture / position.

RULA score analysis aims to determine the level of injury risk to the operators and to find out whether the corrective action is needed from the operators' position or workplace in accordance with the score produced. Based on the data above and categorized in the RULA action level, the work position A is the highest category among the others. It is equal to 8 , so it needs to be conducted as soon as possible, otherwise the operator will experience fatigue faster and also the operator has a greater chance of experiencing injury risk.

\section{CONCLUSION}

The objective of this research is to analyse of operators' working position when producing sandals using the RULA and REBA method at SISCO. Based on the results and analysis of the work position or posture of SISCO operators when carrying out production activities using REBA or RULA method approach. Results indicated that either in the work position/posture A or standing, it has a high risk level with a score of 9 on REBA and 8 on RULA. It means that the work position is not recommended because of the high risk of injury, thus it needs an improvement from the operator's position or the workplace. The position of $\mathrm{B}$ and $\mathrm{C}$ has a moderate score level so it needs an improvement on the position or the work station is in the near future.

\section{ACKNOWLEDGMENT}

Authors would like to thank University of Trunojoyo Madura for providing facilities and places for this research. Authors also thanks to all of students at the Ergonomic and Work System Design Research Group, Sisco's team for their time and cooperation in completing this paper.

\section{REFERENCES}

[1] A. Evan, K. Sejati, and D. Arya, "Analisis Posrtur Kerja Pada Pekerja Konveksi Menggunakan Metode RULA [Analysis of Work Position on 
Convection Workers Using the RULA Method]." Prosiding Seminar Ergonomi [Proceedings of the Ergonomic Seminar], pp. 487-494, 2004

[2] A. Sanjaya, "Aplikasi Rapid Entire Body Assesment (REBA) dalam Perbaikan Postur Kerja [Rapid Entire Body Assessment (REBA) Application in Improving Work Posture]," Prosiding Seminar Nasional Pengukuran Kinerja dan Perencanaan Strategis [Proceedings of the National Seminar on Performance Measurement and Strategic Planning], pp. 85-91, 2002.

[3] B. Suhardi, Perancangan Sistem Kerja dan Ergonomi Industri Untuk SMK [Design of Work Systems and Industrial Ergonomics for Vocational Schools], Direktorat Pembinaan Sekolah Menengah Kejuruan [Directorate of Vocational High School Construction], 2008.

[4] E.N. Corlett, \& T.S. Clark, The Ergonomic of workspaces and machine. A design manual. $2^{\text {nd }}$ edt. Taylor \& Francis. Great Britain, 1995.

[5] L. McAtamney, and E.N. Corlett, "RULA : Survey Method for The Investigation of Work Related Upper Limb Disorder," Applied Ergonomi. Journal of Human Ergonomics,24(2), pp. 91-99. 1993.

[6] L. McAtamney, and S. Hignett, "REBA - A Rapid Entire Body Assesment Method for Investigating Work Related Muskuloskeletal Disorders",Proceedings of Ergonomics Society of Australia Conference. Glenelg, 13 - 15 December. 1995.

[7] L. McAtamney, and S. Hignett, "Rapid Entire Body Assessment", Applied Ergonomics. Elsevier, 31, pp. 201-205, 2000.

[8] L.V. Belleghem, S.D. Gasparo and I. Gaillard, "The development of the psychosocial dimension of work," in Constructive ergonomics: A manifesto, chapter 3, Taylor \& Francis, CRC Press, pp.33-48, 2006.

[9] S. Susilowati, "Pengaruh Posisi Kerja terhadap Produktivitas dan Keluhan Subjektif Karyawan [Effect of Work Position on Productivity and Subjective Complaints of Employees]." Dalam: Wignyosoebroto, S. \& Wiratno, S.E., Eds. Proceedings Seminar Nasional Ergonomi [In: Wignyosoebroto, S. \& Wiratno, S.E., Eds. Proceedings of the National Ergonomics Seminar]. PT. Guna Widya. Surabaya. pp. 219-223, 2000.

[10] S. Wignsoebroto, Ergonomi Studi Gerak dan Waktu. Teknik Analisa untuk Peningkatan Produktivitas Kerja [Ergonomics of Motion and Time Studies. Analysis Techniques for Increasing Work Productivity], 2006.

[11] Tarwaka, L.H.A. Bakrie, and L. sudiajerng, ERGONOMI untuk Kesehatan, Keselamatan Kerja dan Produktivitas [ERGONOMY for Health, Safety and Productivity]. Cetakan pertama [Fist Edition]. UNIBA Press, 2004.

[12] Y. Lémonie, and K. Chassaing, "From the adaptation of movement to the development of gesture," in Constructive ergonomics: A manifesto, chapter 3, Taylor \& Francis, CRC Press, pp.49-64, 2006. 